\title{
Chronic Morphine Treatment Switches the Effect of Dopamine on Excitatory Synaptic Transmission from Inhibition to Excitation in Pyramidal Cells of the Basolateral Amygdala
}

\author{
Zicheng Li, ${ }^{1,2 \star}$ Wenjie Luan, ${ }^{1 \star}$ Yang Chen, ${ }^{1 \star}$ Ming Chen, ${ }^{1}$ Yi Dong, ${ }^{1}$ Bin Lai, ${ }^{1}$ Lan Ma, ${ }^{1}$ and Ping Zheng ${ }^{1}$ \\ ${ }^{1}$ State Key Laboratory of Medical Neurobiology, Shanghai Medical College and Institutes of Brain Science, Fudan University, Shanghai, People's Republic of \\ China 200032, and ${ }^{2}$ Medical College, Three Gorges University, Yi Chang, People's Republic of China 443002
}

\begin{abstract}
Dopaminergic signaling in the basolateral amygdala (BLA) is important for drug-stimulus learning that triggers relapse to drug-seeking behavior. However, little is known about adaptive changes in this signaling pathway upon chronic morphine treatment. In this paper, we observed the influence of chronic morphine treatment on the effect of dopamine (DA) on the excitatory transmission in the pyramidal cells of BLA in slices with the whole-cell patch-clamp method. We also studied its mechanism and significance with pharmacological approaches combined with biochemical and behavioral techniques. The results showed that chronic morphine exposure switched the effect of DA on the excitatory synaptic transmission from inhibition to excitation; the chronic morphine-induced switching action on the effect of DA was due to its influence on D1 receptors; the site of the effect of chronic morphine treatment on D1 receptors was at presynaptic locus; chronic morphine treatment induced a significant increase in the amount of D1 receptor expression in the synaptosomes and synaptosomal membrane fraction from BLA; the enhancement of presynaptic glutamate release by D1 receptor agonist upon chronic morphine treatment was dependent on the activation of cAMP-dependent protein kinase; and the intra-BLA injection of D1 receptor antagonist canceled the conditioned place aversion (CPA) in morphine-dependent rats. In conclusion, chronic morphine treatment switches the effect of DA on the excitatory synaptic transmission from inhibition to excitation by the presynaptic D1 receptor amount increase-mediated glutamate release in the pyramidal cells of BLA and the blockade of D1 receptors in BLA cancels CPA in morphine-dependent rats.
\end{abstract}

\section{Introduction}

Morphine addiction is a state of compulsive morphine use (Hyman et al., 2006). The consequences of repeated morphine use include increased drug craving, tolerance to morphine analgesia, and expression of somatic and affective withdrawal syndromes with dysphoria, anxiety, and depression when the drug is discontinued (Kreek, 2001). Moreover, all these features are a result of adaptive changes in the brain (McClung et al., 2005). Therefore, the study of the chronic morphine-induced adaptations in the

Received July 25, 2011; revised 0ct. 14, 2011; accepted 0ct. 19, 2011.

Author contributions: Z.L., W.L., Y.C., L.M., and P.Z. designed research; Z.L., W.L., Y.C., M.C., Y.D., and B.L. performed research; P.Z. contributed unpublished reagents/analytic tools; Z.L., W.L., Y.C., M.C., Y.D., B.L., and P.Z. analyzed data; Z.L., W.L., Y.C., and P.Z. wrote the paper.

This work was supported by Projects 30900424 and 30821002 of Foundation of National Natural Science of China, the National Program of Basic Research sponsored by the Ministry of Science and Technology of China (2009CB52201), and Project B119 of Shanghai Leading Academic Discipline. We thank Dr. Jun Chen at the University of Pittsburgh for critically reading this manuscript and offering many suggestions during the revision.

*Z.L., W.L., and Y.C. contributed equally to this paper.

Correspondence should be addressed to Dr. Ping Zheng, State Key Laboratory of Medical Neurobiology, Shanghai Medical College, Fudan University, 138 Yixueyuan Road, Shanghai, 200032, People's Republic of China. E-mail: pzheng@shmu.edu.cn.

DOI:10.1523/JNEUROSCI.3806-11.2011

Copyright $\odot 2011$ the authors $\quad 0270-6474 / 11 / 3117527-10 \$ 15.00 / 0$ brain is of significant importance for understanding the mechanism of morphine addiction.

Among various brain adaptive changes induced by repeated morphine exposure, changes in the dopaminergic system, especially in the mesocorticolimbic dopaminergic system, are considered crucial for morphine dependence (Di Chiara and North, 1992). Observations indicate that morphine abuse is a dopaminedependent disorder in which the positive reinforcing value of the drug is mediated through the activation of the mesocorticolimbic dopaminergic system (Di Chiara, 1999). This activation also has been proposed to be responsible for disturbances in motivational and emotional processes underlying addiction (Ziolkowska et al., 2005). However, the morphine-induced adaptive alterations in different parts of the mesocorticolimbic dopaminergic system remain to be studied.

The mesocorticolimbic dopaminergic system consists of dopaminergic neurons in the ventral tegmental area (VTA) and their various projection regions, such as the prefrontal cortex (PFC), nucleus accumbens (NAc), and basolateral amygdala (BLA). Previous studies have examined the morphine-induced adaptive changes in VTA, PFC, and NAc. It has been reported that chronic morphine treatment can cause functional changes in dopamine-containing neurons that spread widely within these 
A

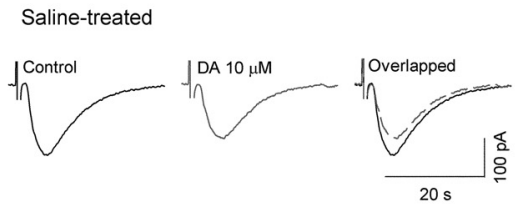

Morphine-treated
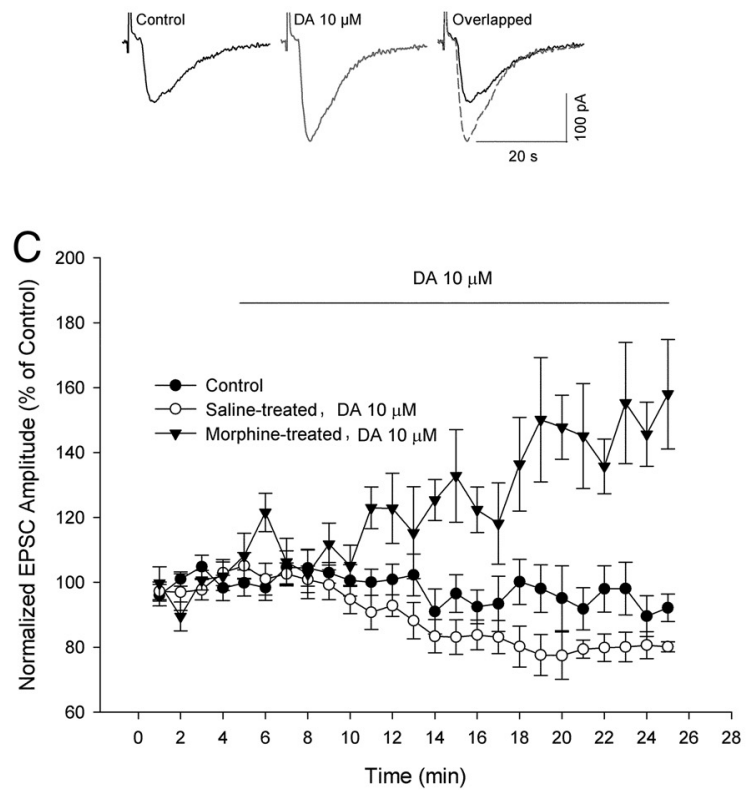
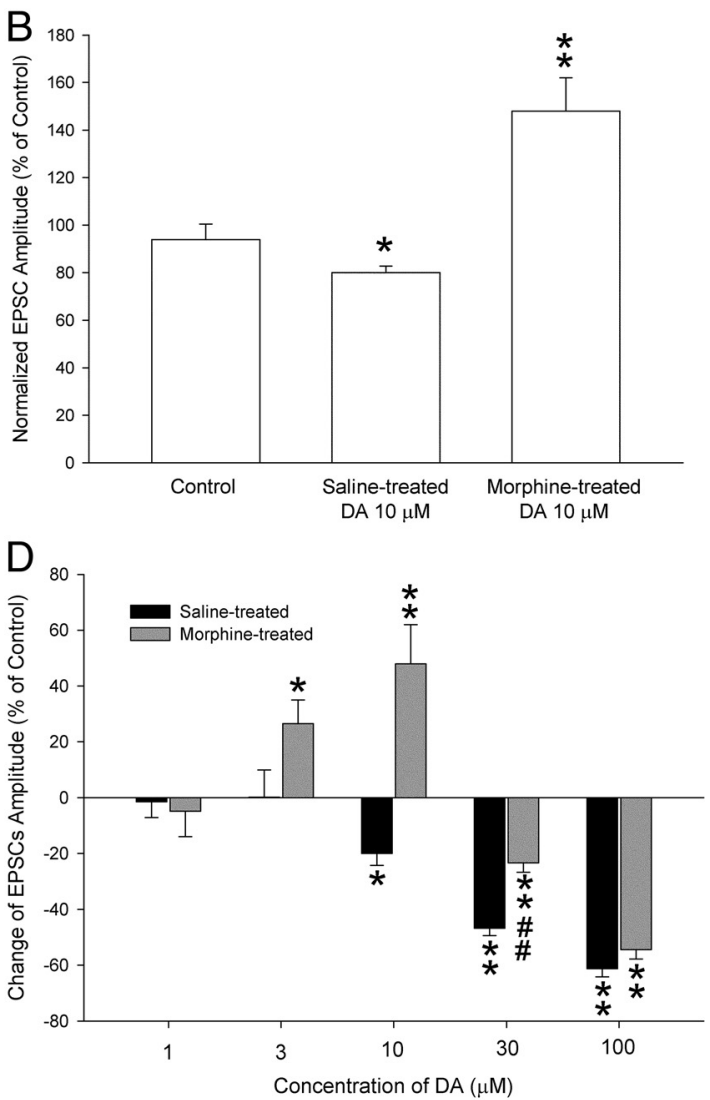

Figure 1. Influence of chronic morphine exposure on the effect of dopamine on the excitatory synaptic transmission in the pyramidal cells of BLA. $\boldsymbol{A}$, Typical recordings of EPSC before and after dopamine (10 $\mu \mathrm{M}$ ) in the slice from the saline-treated (top) and chronic-morphine-treated (bottom) rats. Holding potential, $-70 \mathrm{mV}$. $\boldsymbol{B}$, The averaged percentage of the inhibition of EPSC by $10 \mu \mathrm{M}$ dopamine in the slices from saline-treated (middle bar) and morphine-treated (right bar) rats ( $n=6,{ }^{*} p<0.05,{ }^{* *} p<0.01$, compare to control). C, Time course of EPSC before and after dopamine $(10 \mu \mathrm{m})$ in the slice from the saline-treated (open circles) and chronic-morphine-treated (filled triangles) rats $(n=6)$. $\boldsymbol{D}$, Influence of chronic morphine treatment on the effect of different concentrations of dopamine $\left(n=6,{ }^{*} p<0.05,{ }^{* *} p<0.01\right.$, compared with control; ${ }^{\# \#} p<0.01$, compared with dopamine group in saline-treated rats).

regions and results in an increase in neuronal activity and dopamine release from their nerve terminals (Berridge and Robinson, 1998; Spanagel and Weiss, 1999; Schultz, 2000). In addition, morphine-induced adaptive changes in postsynaptic parts of dopaminergic projections in NAc and PFC also have been reported (Ito et al., 2007; Glass et al., 2008; Narita et al., 2010). However, little is known about adaptive changes in dopaminergic signaling in BLA upon chronic morphine treatment.

Dopaminergic signaling in BLA is important for rewardrelated learning and drug-stimulus learning that triggers relapse to drug-seeking behavior (Nakano et al., 1987; Harmer and Phillips, 1999; Andrzejewski et al., 2005; Di Ciano and Everitt, 2005; See, 2005). The major targets of dopamine terminals in BLA are pyramidal cells that send projections to other brain regions. At least $77 \%$ of dopamine terminals form synapses in BLA and $90 \%$ of these synapses are with pyramidal cells (Muller et al., 2009). Moreover, in the pyramidal cells of BLA, dopaminergic inputs are well positioned to modulate glutamatergic synaptic transmission, which is critical for driving neuronal activity in BLA (Sesack et al., 2003; Pinto and Sesack, 2008). Therefore, it is important to examine adaptive changes in the modulatory effect of dopamine on the glutamatergic synaptic transmission in the pyramidal cells of BLA upon chronic morphine treatment. In this study, we first observed the effect of dopamine alone on the excitatory synaptic transmission in the pyramidal cells of BLA by examining the effect of dopamine on stimulus-evoked EPSCs in BLA slices with the whole-cell patch-clamp method and then studied the influ- ence of chronic morphine treatment on the effect of dopamine. We also further studied its mechanism and functional significance with pharmacological approaches combined with biochemical and behavioral techniques.

\section{Materials and Methods}

Chronic morphine treatment. Male Sprague Dawley rats (16-18 d old) were treated with morphine according to procedures described previously (Desjardins et al., 2008). Briefly, morphine dependence was induced in rats by repeated intraperitoneal injections of morphine twice daily at 8:00 A.M. and 7:00 P.M. Morphine doses were progressively increased from 10 to $40 \mathrm{mg} / \mathrm{kg}$ : first day, $2 \times 10 \mathrm{mg} / \mathrm{kg}$; second day, $2 \times$ $20 \mathrm{mg} / \mathrm{kg}$; third day, $2 \times 30 \mathrm{mg} / \mathrm{kg}$; fourth and fifth days, $2 \times 40 \mathrm{mg} / \mathrm{kg}$. Control rats were treated with saline following the same procedure.

Preparation of BLA slices and whole-cell recording. Rats were anesthetized with chloral hydrate $(400 \mathrm{mg} / \mathrm{kg}$, i.p.). All experimental procedures conformed to Fudan University and international guidelines on the ethical use of animals. All efforts were made to minimize animal suffering and to reduce the number of animals used. Brain slices were prepared according to procedures described previously (Wang and Zheng, 2001). Briefly, following decapitation, the brain was quickly removed and submerged in ice-cold artificial CSF (ACSF) containing the following (in m): $126 \mathrm{NaCl}, 5 \mathrm{KCl}, 2 \mathrm{CaCl}_{2}, 2 \mathrm{MgSO}_{4}, 1.25 \mathrm{NaH}_{2} \mathrm{PO}_{4}, 26 \mathrm{NaHCO}_{3}$, 10 glucose, 10 sucrose and saturated with $95 \% \mathrm{O}_{2} / 5 \% \mathrm{CO}_{2}$. A block of tissue containing BLA was cut and placed on a layer of moistened filter paper glued to the cutting stage of a vibratome (VT1000M/E; Leica). Serial coronal slices $(300 \mu \mathrm{m})$ were cut and transferred to an incubating chamber $\left(30-32^{\circ} \mathrm{C}\right)$, where they stayed for at least $1 \mathrm{~h}$ before recordings were begun. In chronic-morphine-treated rats, brain slices were pre- 
A

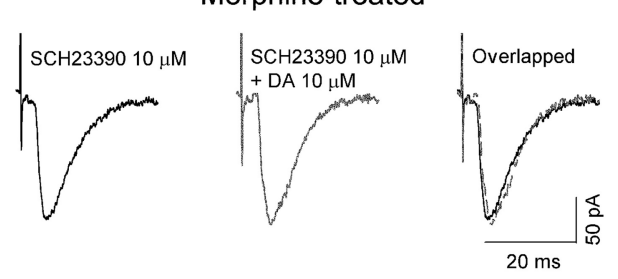

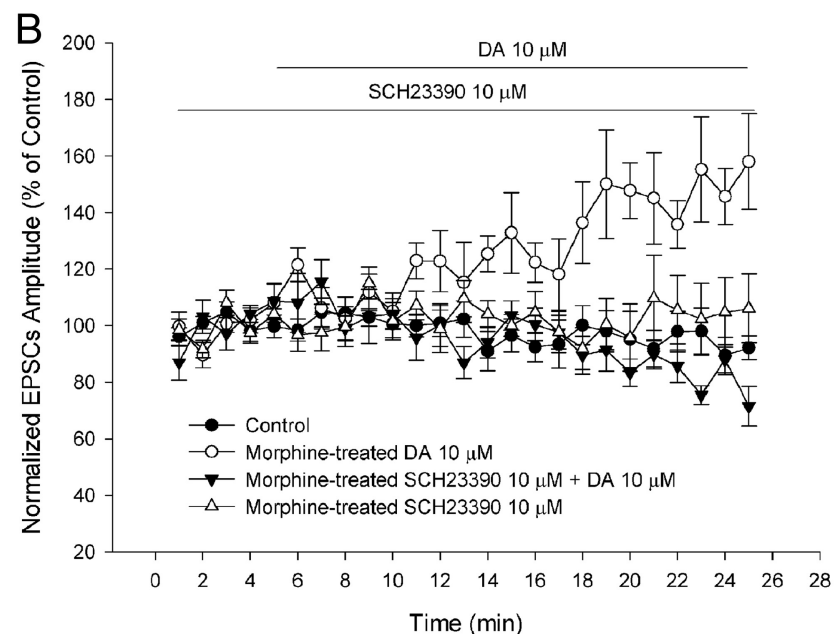

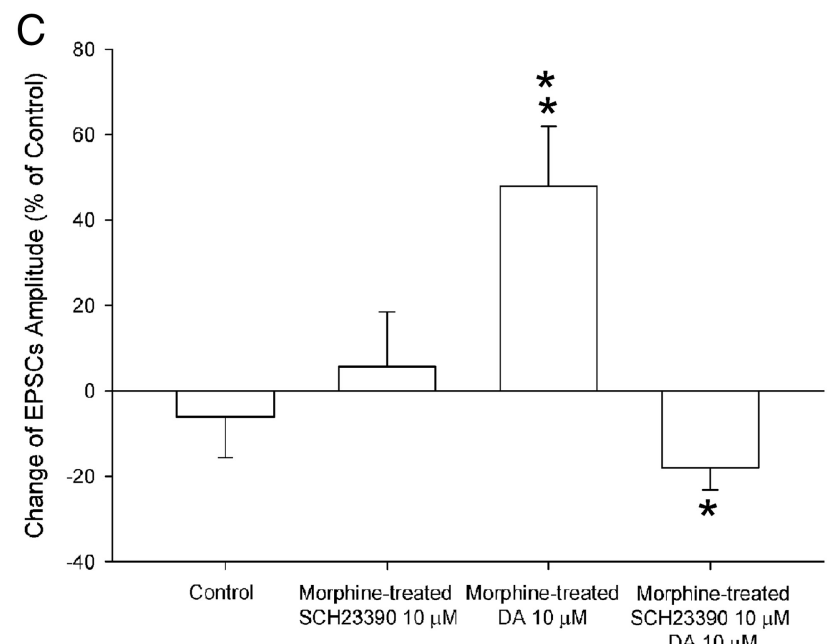

Figure 2. Influence of D1 receptor antagonist on the chronic-morphine-induced change in the effect of dopamine in the pyramidal cells of BLA. $A$, Typical recordings of EPSC before and after dopamine $(10 \mu \mathrm{M})$ in the presence of the D1 receptor antagonist SCH23390 (10 $\mu \mathrm{m})$ in the slice from the chronic-morphine-treated rat. Holding potential, $-70 \mathrm{mV}$. B, Time course of EPSC before and after dopamine $(10 \mu \mathrm{M})$ in the presence of $\mathrm{SCH} 23390(10 \mu \mathrm{m})$ in the slices from the chronic-morphine-treated rats $(n=6)$. C, Averaged percentage of the effect of dopamine (10 $\mu \mathrm{m})$ on EPSC in the presence of SCH23390 $(10 \mu \mathrm{M})$ in the slices from the chronic-morphine-treated rats $\left(n=6,{ }^{*} p<0.05,{ }^{* *} p<0.01\right.$, compared with control).

pared $4 \mathrm{~h}$ after the last injection of morphine and maintained in vitro in 5 $\mu \mathrm{M}$ morphine throughout the experiments.

Pyramidal cells of BLA were visualized using infrared Nomarski optics. Whole-cell voltage-clamp recordings were made using patch electrodes (2-3 M $\Omega$ ) containing the following (in $\mathrm{mM}$ ): $140 \mathrm{~K}$-gluconate, $0.1 \mathrm{CaCl}_{2}$, $2 \mathrm{MgCl}_{2}, 1 \mathrm{EGTA}, 2 \mathrm{ATP} \cdot \mathrm{K}_{2}, 0.1 \mathrm{GTP} \cdot \mathrm{Na}_{3}$, and $10 \mathrm{HEPES}, \mathrm{pH} 7.4$. Voltage and current signals were recorded with an Axopatch 200B amplifier (Axon) connected to a Digidata1200 interface (Axon). The data were digitized and stored on disks using pClamp (version 6; Axon). Resting membrane potential and action potentials were recorded under the current-clamp mode. Cells were held at $-70 \mathrm{mV}$ under a voltageclamp mode to record EPSCs. A concentrated stimulating electrode (FHC) was placed near the external capsule, 200-300 $\mu \mathrm{m}$ laterally to the recorded cell. Picrotoxin $(50 \mu \mathrm{M})$ was included in ACSF to block $\mathrm{GABA}_{\mathrm{A}}$ receptors. Stimulating pulses were given at $0.05 \mathrm{~Hz}$ with the stimulation intensity adjusted to evoke an EPSC that was $\sim 30-40 \%$ of the maximum amplitude, usually $\sim 200 \mathrm{pA}$. To observe paired pulse facilitation (PPF), two synaptic responses were evoked by a pair of stimuli given at short intervals $(50 \mathrm{~ms})$ at $0.05 \mathrm{~Hz}$. Miniature EPSCs (mEPSCs) were recorded in sweeps of $2 \mathrm{~s}$ at a holding potential of $-70 \mathrm{mV}$ under the voltageclamp mode in the presence of tetrodotoxin (TTX; $0.5 \mu \mathrm{M}$ ) and picrotoxin $(50 \mu \mathrm{M})$ to block voltage-dependent sodium channels and $\mathrm{GABA}_{\mathrm{A}}$ receptors, respectively. The series resistance $\left(R_{s}\right)$ was monitored by measuring the instantaneous current in response to a $5 \mathrm{mV}$ voltage step command. Series resistance compensation was not used, but cells where Rs changed by $>15 \%$ were discarded.
Synaptosome preparation. Male Sprague Dawley rats (200-240 g) were anesthetized with chloral hydrate ( $400 \mathrm{mg} / \mathrm{kg}$, i.p.). Synaptosomes were prepared as described previously (Dong et al., 2005). The amygdala was dissected and homogenized in $0.32 \mathrm{M}$ sucrose solution at $4^{\circ} \mathrm{C}$ using the Art-Miccra D-8 tissue grinder with a motor-driven pestle rotating at 900 $\mathrm{rpm}$. The homogenate was centrifuged at $3000 \times g$ for $3 \mathrm{~min}$ at $4^{\circ} \mathrm{C}$. The supernatant was centrifuged at $14,500 \times g$ for $12 \mathrm{~min}$ at $4^{\circ} \mathrm{C}$. The pellet was resuspended and loaded onto Percoll gradients consisting of three steps of 23,10 , and $3 \%$ Percoll in $0.32 \mathrm{~m}$ sucrose additionally containing $1 \mathrm{~mm}$ EDTA and $250 \mu \mathrm{M}$ DTT. The gradients were centrifuged at $32,500 \times g$ for $6.5 \mathrm{~min}$ at $4^{\circ} \mathrm{C}$. Synaptosomes were harvested from the interface between the 23 and 10\% Percoll layers and washed in HBSS containing the following (in mM): $140 \mathrm{NaCl}, 5 \mathrm{KCl}, 5 \mathrm{NaHCO}_{3}, 1 \mathrm{MgCl}_{2}$, $1.2 \mathrm{Na}_{2} \mathrm{HPO}_{4}, 10$ glucose, and $20 \mathrm{HEPES}, \mathrm{pH}$ 7.4. Washed synaptosomes were centrifuged at $27,000 \times g$ for $15 \mathrm{~min}$ at $4^{\circ} \mathrm{C}$. The protein concentration of the synaptosomes was determined by the method described by Lowry et al. (1951) with bovine serum albumin as the standard protein.

Synaptosomal membrane preparation. Isolation of synaptosomal membrane fraction was performed as described previously (Visanji et al., 2011), with slight modifications. Briefly, synaptosomal pellets were transferred immediately to ice-cold buffer A ( $140 \mathrm{~mm} \mathrm{NaCl}, 5 \mathrm{~mm} \mathrm{KCl}$, $20 \mathrm{~mm}$ HEPES, $5 \mathrm{~mm} \mathrm{NaHCO}$, $1.2 \mathrm{~mm} \mathrm{Na}_{2} \mathrm{HPO}_{4}, 1 \mathrm{~mm} \mathrm{MgCl}, 1 \mathrm{~mm}$ EGTA, and $10 \mathrm{~mm}$ glucose) and then centrifuged at 24,000 $\times \mathrm{g}$ for 10 min. The pellets were lysed in buffer B (10 mM HEPES, 18 mм KOAc, $\mathrm{pH}$ 7.2) followed by centrifugation at $24,000 \times g$ for $10 \mathrm{~min}$ and resuspended 


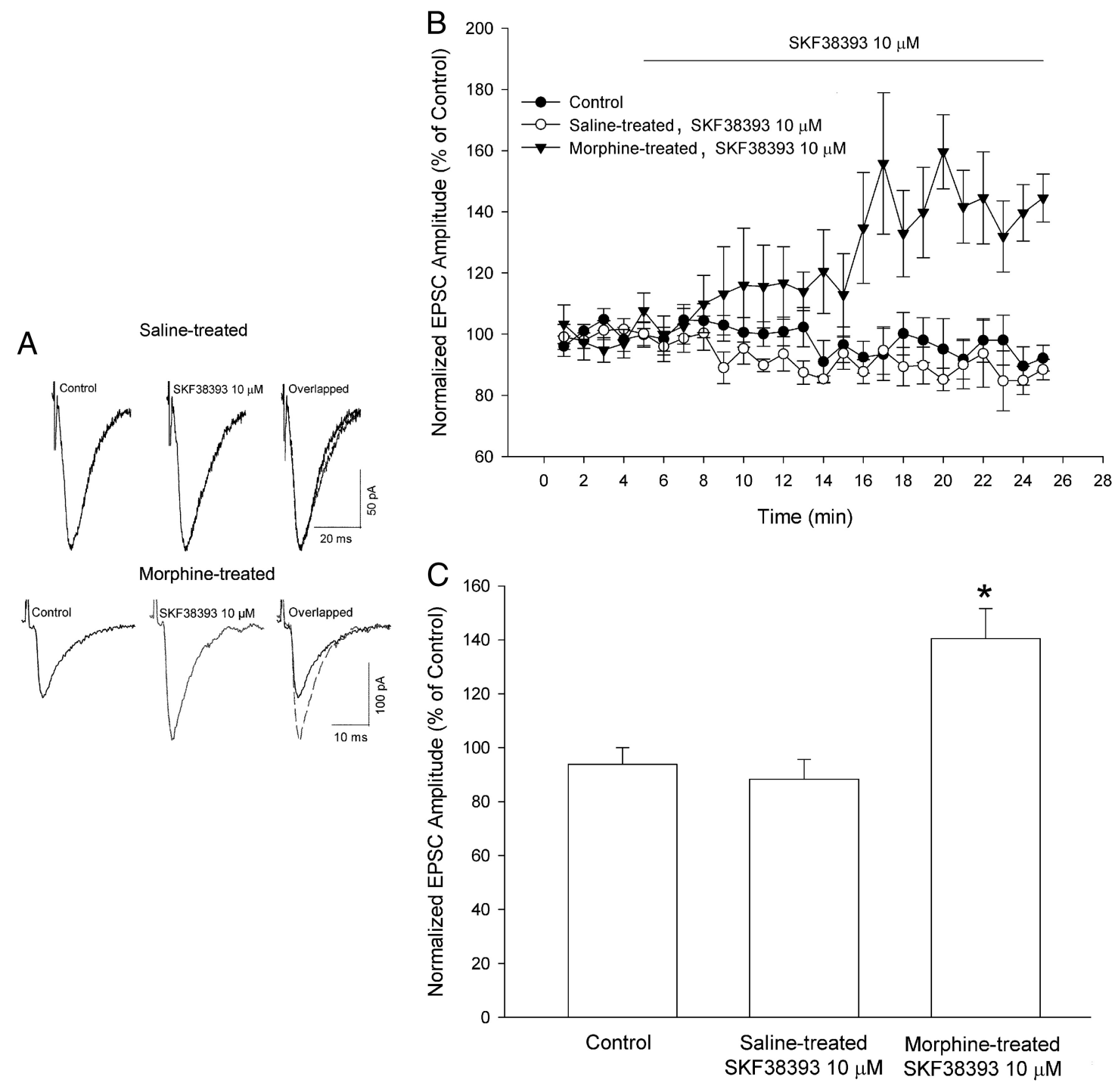

Figure 3. Effect of D1 receptor agonist on EPSC in the pyramidal cells of BLA in the saline-treated and chronic-morphine-treated rats. A, Typical recordings of EPSC before and after SKF38393 (10 $\mu \mathrm{M}$ ) in the slice from the saline-treated (top) and chronic-morphine-treated (bottom) rats. Holding potential, $-70 \mathrm{mV}$. B, Time course of EPSC before and after SKF 38393 (10 $\mu \mathrm{m}$ ) in the slices from the saline-treated (open circles) and chronic-morphine-treated (filled triangles) rats $(n=6)$. C, Averaged percentage of the effect of SKF38393 (10 $\mu \mathrm{M})$ on EPSC in the slices from the saline-treated (middle bar) and chronic-morphine-treated (right bar) rats $\left(n=6,{ }^{*} p<0.05\right.$, compared with control).

in buffer C (25 mm HEPES, $125 \mathrm{~mm} \mathrm{KOAc}$, and $\left.2.5 \mathrm{~mm} \mathrm{MgCl}_{2}\right)$ to yield synaptosomal membrane fractions.

Assessment of cAMP-dependent protein kinase activity. The activity of protein kinase (PKA) was assessed with PepTag Non-Radioactive PKA assay kits from Promega. The assay was based on the change in the net charge of the fluorescent PKA substrate before and after phosphorylation. This change in the net charge of the substrate allowed the phosphorylated and nonphosphorylated version of the substrate to be rapidly separated on an agarose gel at neutral $\mathrm{pH}$. The PKA activity was quantified based on the intensity of the fluorescence of the phosphorylated peptide (Lou and Pei, 1997).

Western blotting. Immunoblot analysis of D1 and D2 receptors was performed on the synaptosomes and synaptosomal membrane fractions from the amygdala. The synaptosomal pellets were homogenized in a buffer containing $100 \mathrm{~mm}$ Tris- $\mathrm{HCl}, \mathrm{pH}$ 6.7, 1\% SDS, $143 \mathrm{~mm}$ 2-mercaptoethanol, and $1 \%$ protease inhibitor. The lysate was centrifuged at $12,000 \mathrm{rpm}$ for $10 \mathrm{~min}$ at $4^{\circ} \mathrm{C}$. Protein concentrations were determined using a BCA kit (Pierce Chemicals). The samples were treated with the SDS sample buffer at $95^{\circ} \mathrm{C}$ for 5 min, loaded on a $10 \%$ SDS polyacrylamide gel and blotted to a PVDF membrane. Each blot was incubated with a rabbit anti-D1 receptor antibody (1:1000; Abcam), a rabbit anti-D2 receptor antibody (1:1000; Millipore Bioscience Research Reagents), or a monoclonal anti- $\beta$-actin antibody (1:4000; Cell Signaling Technology). The horseradish peroxidase development system previously described (Moore et al., 1998) was used for immunodetection. The immunoreactivity of D1 and D2 receptors was normalized to that of $\beta$-actin. Each experiment was repeated at least five times.

Surgical and intra-BLA injection procedures. Male Sprague Dawley rats $(\sim 300 \mathrm{~g})$ were used. The animals were housed in groups of four in a temperature $\left(22^{\circ} \mathrm{C}\right)$-controlled colony room and maintained on a standard $12 \mathrm{~h}$ light/dark cycle with food and water ad libitum. The rats were anesthetized with sodium pentobarbital $(60 \mathrm{mg} / \mathrm{kg}$, i.p.) after pretreatment with atropine sulfate $(0.5 \mathrm{mg} / \mathrm{kg}$, i.p. $)$ and placed in a stereotaxic instrument (Narishige). Two 24-gauge stainless-steel guide cannulae were implanted bilaterally $2 \mathrm{~mm}$ above BLA. The coordinates were based on the atlas of Paxinos and Watson (2005): AP, $-2.8 \mathrm{~mm}$ from bregma; $\mathrm{ML}, \pm 5.0 \mathrm{~mm}$ from midline; DV, $-6.5 \mathrm{~mm}$ from skull surface. The cannulae were secured to the skull with two anchoring screws and dental cement. Wire plugs (30 gauge) were inserted into the cannulae to prevent occlusion. After surgery, animals were housed individually and were allowed to recover for more than a week. For microinjection, 30-gauge injection needles were inserted into the cannulae. The injection needles 
A

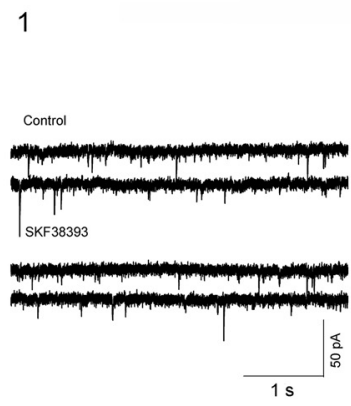

B

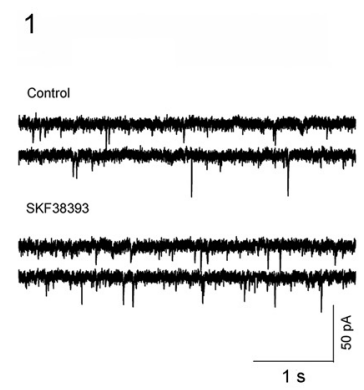

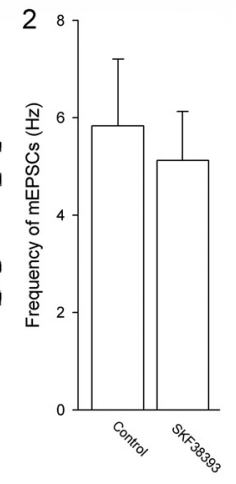

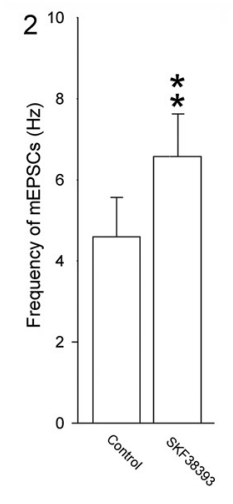

Saline-treated
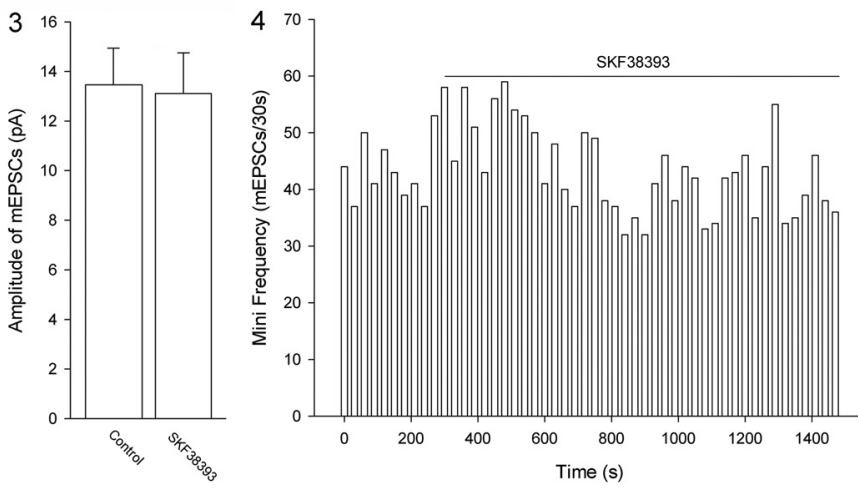

Morphine-treated
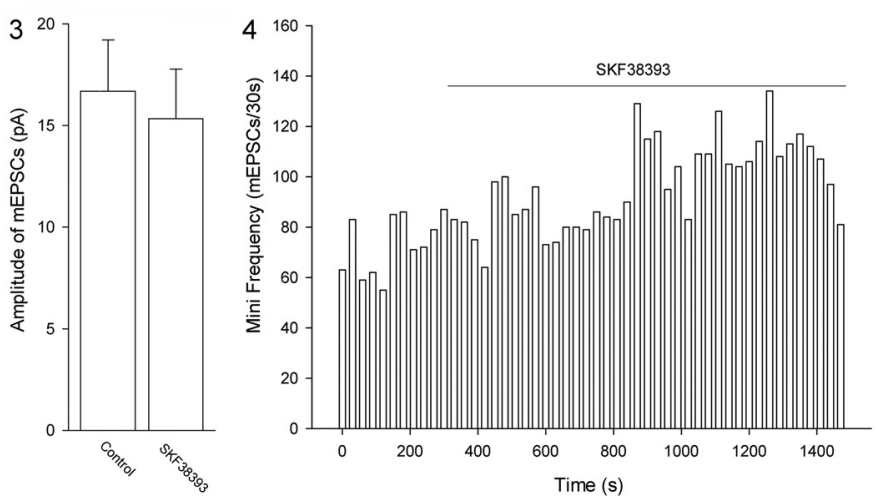

Figure 4. Effect of D1 receptor agonist on the frequency and amplitude of $m E P S C s$ in the pyramidal cells of BLA in the saline-treated and chronic-morphine-treated rats. $A$, Effect of D1 receptor agonist on the frequency and amplitude of $\mathrm{mEPSCs}$ in the pyramidal cells of BLA in the saline-treated rats. A1, Typical recordings of mEPSCs before and after SKF38393 (10 $\mu \mathrm{M})$ in the slice from the saline-treated rat. Holding potential, $-70 \mathrm{mV}$. A2, Averaged frequency of mEPSCs before and after SKF38393 (10 $\mu \mathrm{m})(n=6)$. A3, Averaged amplitude of mEPSCs before and after SKF38393 (10 $\mu \mathrm{M})(n=6)$. A4, Time course of the frequency of mEPSCs in a typical cell before and after SKF38393 $(10 \mu \mathrm{m}) . \boldsymbol{B}$, Effect of D1 receptor agonist on the frequency and amplitude of $\mathrm{mEPSC}(\mathrm{s}$ in the pyramidal cells of BLA in chronic-morphine-treated rats. B1, Typical recordings of mEPSCs before and after SKF38393 (10 $\mu \mathrm{m})$ in the slice from the saline-treated rat. Holding potential, $-70 \mathrm{mV}$. $B 2$, Averaged frequency of mEPSCs before and after SKF38393 $(10 \mu \mathrm{m})\left(n=6,{ }^{* *} p<0.01\right.$, compared with control). B3, Averaged amplitude of $\mathrm{mEPSCS}$ before and after SKF38393 (10 $\left.\mu \mathrm{m}\right)(n=$ 6). B4, Time course of the frequency of mEPSCs in a typical cell before and after SKF38393 $(10 \mu \mathrm{M})$.

were connected to a $1 \mu \mathrm{l}$ microsyringe (Hamilton) by polyethylene tubing and controlled by a syringe pump (Harvard Apparatus). Rats were bilaterally injected with $0.5 \mu \mathrm{l}$ of SCH $23390(0.5 \mu \mathrm{g} /$ side $)$ or saline for 1 $\mathrm{min}$. After the injection, the needles were left in place for another $1 \mathrm{~min}$.

Behavioral testing. The procedure for conditioned place aversion (CPA) test was similar to that described previously (Valverde et al., 1996), with some modification. CPA was conducted with a threecompartment place conditioning apparatus (Med Associates). On day 0, the rats were given a preconditioning test (Pretest). The animals were placed in the middle neutral area and were allowed to freely access both sides of the apparatus for $15 \mathrm{~min}$. Rats with a strong preference $(>60 \%)$ for any compartment were discarded. Before conditioning, morphine dependence was induced by twice daily intraperitoneal injections of morphine at 8:00 A.M. and 7:00 P.M. The morphine dose was progressively increased by $10 \mathrm{mg} / \mathrm{kg}$ increments from $10 \mathrm{mg} / \mathrm{kg}$ on day 1 to 40 $\mathrm{mg} / \mathrm{kg}$ on day 4 , and this dose was maintained on days 5 and 6 . On day 5 , $3 \mathrm{~h}$ after $40 \mathrm{mg} / \mathrm{kg}$ morphine administration, rats were confined to either compartment for $20 \mathrm{~min}$ immediately after the subcutaneous injection of naloxone $(0.1 \mathrm{mg} / \mathrm{kg})$. On day 6 , rats were confined to the opposite compartment for $20 \mathrm{~min}$ after the subcutaneous injection of saline. Intracranial microinjections were performed before the subcutaneous injection of naloxone or saline. The test was conducted $24 \mathrm{~h}$ after conditioning on day 7 . The rats were allowed to freely explore three compartments for $15 \mathrm{~min}$ and CPA score was calculated as difference between the time spent in the saline-paired compartment and the time spent in the naloxone-paired compartment (time in the naloxone-paired compartment minus time in the saline-paired compartment). After the behavioral tests, all rats were anesthetized with an overdose of sodium pentobarbital and perfused with $0.9 \%$ saline. The brain was removed and fixed in $4 \%$ paraformaldehyde for $24 \mathrm{~h}$. Coronal sections $(50 \mu \mathrm{m})$ were cut by a vibratome and stained with cresyl violet. Injection sites were verified under light microscope.

Drug. $\mathrm{N}$-[2-(p-bromocinnamylamino) ethyl]-5-isoquinolinesulfonamide dihydrochloride (H89), ( \pm )-1-phenyl-2,3,4,5-tetrahydro-(1H)-3-benzazepine-7,8-diol hydrobromide (SKF38393), R(+)-7-chloro-8-hydroxy-3methyl-1-phenyl-2,3,4,5-tetrahydro-1H-3-benzazepine hydrochloride (SCH23390), DMSO, sulpiride, dopamine (DA), picrotoxin, ATP $\cdot \mathrm{K}_{2}$, GTP. $\mathrm{Na}_{3}$, HEPES, SDS, and EGTA were purchased from Sigma. Morphine was from Shenyang No.1 Pharmaceutical Factory. TTX was made in the Research Institute of Aquatic Products of Hebei, China. Non-radioactive PKA assay kit was from Promega. Percoll was purchased from GE Healthcare. D1 receptor antibody was from Abcam, D2 receptor antibody was from Millipore Bioscience Research Reagents, and $\beta$-actin antibody was from Santa Cruz Biotechnology. Other reagents in AR grades were products of Shanghai Chemical Plant. Picrotoxin and $\mathrm{H} 89$ were dissolved in DMSO and others were dissolved in $\mathrm{ddH}_{2} \mathrm{O}$. When DMSO was used as the vehicle, drugs were initially dissolved in 100\% DMSO and then diluted into ACSF or HBSS at a final DMSO concentration $<0.5 \%$, which had no detectable effects on the parameters we observed. SKF38393 and dopamine were dissolved in distilled water just before use.

Off-line data analysis. Off-line data analysis was performed using a Mini Analysis Program (Synaptosoft), SigmaPlot (Jandel Scientific), and Origin (Microcal Software). The records of mEPSCs were shown with high-time resolution, and events that did not show a typical EPSC waveform were rejected manually. The frequency and amplitude of mEPSCs were measured. In most cases, $>100$ mEPSCs were collected under 
control conditions as well as for each pharmacological condition $[\mathrm{PPF}=(\mathrm{EPSC} 2-$ EPSC1)/EPSC1 $\times 100 \%]$. Numerical data were expressed as mean \pm SE. Statistical significance was determined using Student's paired $t$ test for comparisons between two groups or ANOVA followed by Student-Newman-Keuls test for comparisons among three or more groups. In all cases, $n$ refers to the number of cells or synaptosomal samples studied. In the patch-clamp studies, every cell was from a different slice and a group of cells in each experiment was from at least four animals. In the synaptosomal experiments, different synaptosomal samples came from different animals.

\section{Results}

Chronic morphine exposure switches the effect of dopamine on excitatory synaptic transmission from inhibition to excitation in the pyramidal cells of BLA

The effect of dopamine on the amplitude of EPSC in the pyramidal cells of BLA was examined and a range of $1-100 \mu \mathrm{M}$ dopamine was used in the experiments, as several previous studies showed that $10-100$ $\mu \mathrm{M}$ dopamine were necessary to induce the effects on synaptic transmission under in vitro conditions (Momiyama et al., 1996; Nicola et al., 1996; Zhou and Hablitz, 1999; Seamans et al., 2001). From typical recordings of EPSC, it was shown that, in the slice from saline-treated rat, dopamine at $10 \mu \mathrm{M}$ inhibited the amplitude of EPSC by $~ 20 \%$; however, in the slice from chronic-morphine-treated rat, dopamine at $10 \mu \mathrm{M}$ increased the amplitude of EPSC by 50\% above the control level (Fig. 1A). The experiments were repeated using six slices from at least four different animals and similar results were obtained at 20 min after dopamine exposure (Fig. $1 B$ ). These results showed that morphine treatment switched the effect of dopamine on EPSC from inhibition to potentiation. Figure $1 C$ illustrates the time course of EPSC responses under dopamine (10 $\mu \mathrm{M})$ exposure in saline- and morphine-treated slices, which showed that the switching action of chronic morphine treatment on EPSC began at $10-12 \mathrm{~min}$ and reached the plateau at $\sim 20 \mathrm{~min}$ after dopamine exposure. Figure $1 D$ illustrates the effects of morphine treatment on EPSC under a range of dopamine concentrations. In saline-treated slices, increased concentrations of dopamine resulted in greater inhibitory effect on EPSC, reaching $>40 \%$ inhibition at $30 \mu \mathrm{M}$ and $>60 \%$ inhibition at $100 \mu \mathrm{M}$; in contrast, morphine treatment significantly attenuated the inhibitory effect of $30 \mu \mathrm{M}$ dopamine on EPSC, whereas it had no effect on EPSC when dopamine concentration was increased to $100 \mu \mathrm{M}$ (Fig. $1 D)$. These results suggest that the potentiation effect of morphine treatment on EPSC is lost under dopamine concentrations of $>30 \mu \mathrm{M}$. Given the striking effect of chronic morphine treatment on EPSC at $<10 \mu \mathrm{M}$ dopamine, this concentration of dopamine was used in all mechanistic studies described below.
We also examined the effect of acute application of morphine into the chamber of slices on dopamine-induced inhibition of EPSC. The mean percentages of the inhibition of EPSC by dopamine $(10 \mu \mathrm{M})$ after the acute application of morphine $(5 \mu \mathrm{M})$ were $19.8 \pm 4.9 \%(n=6)$, which was not significantly different $(p>0.05)$ from that of dopamine with saline treatment $(20.0 \pm$ $2.8 \% ; n=6)$.

\section{Chronic morphine-induced switching action on the effect of dopamine is due to its influence on $\mathrm{D} 1$ receptors}

To study the mechanism of the chronic morphine-induced switching action on the effect of dopamine, we observed the influence of the D1 receptor antagonist SCH23390 (Michaeli and Yaka, 2010) on the switching action. The result showed that in saline-treated rats, SCH23390 $(10 \mu \mathrm{M})$ had no effect on the dopamine-induced inhibition of EPSC, but in chronicmorphine-treated rats, the enhancement of EPSC by dopamine $(10 \mu \mathrm{M})$ was completely blocked by SCH23390 ( $n=6$; Fig. 2 ). 

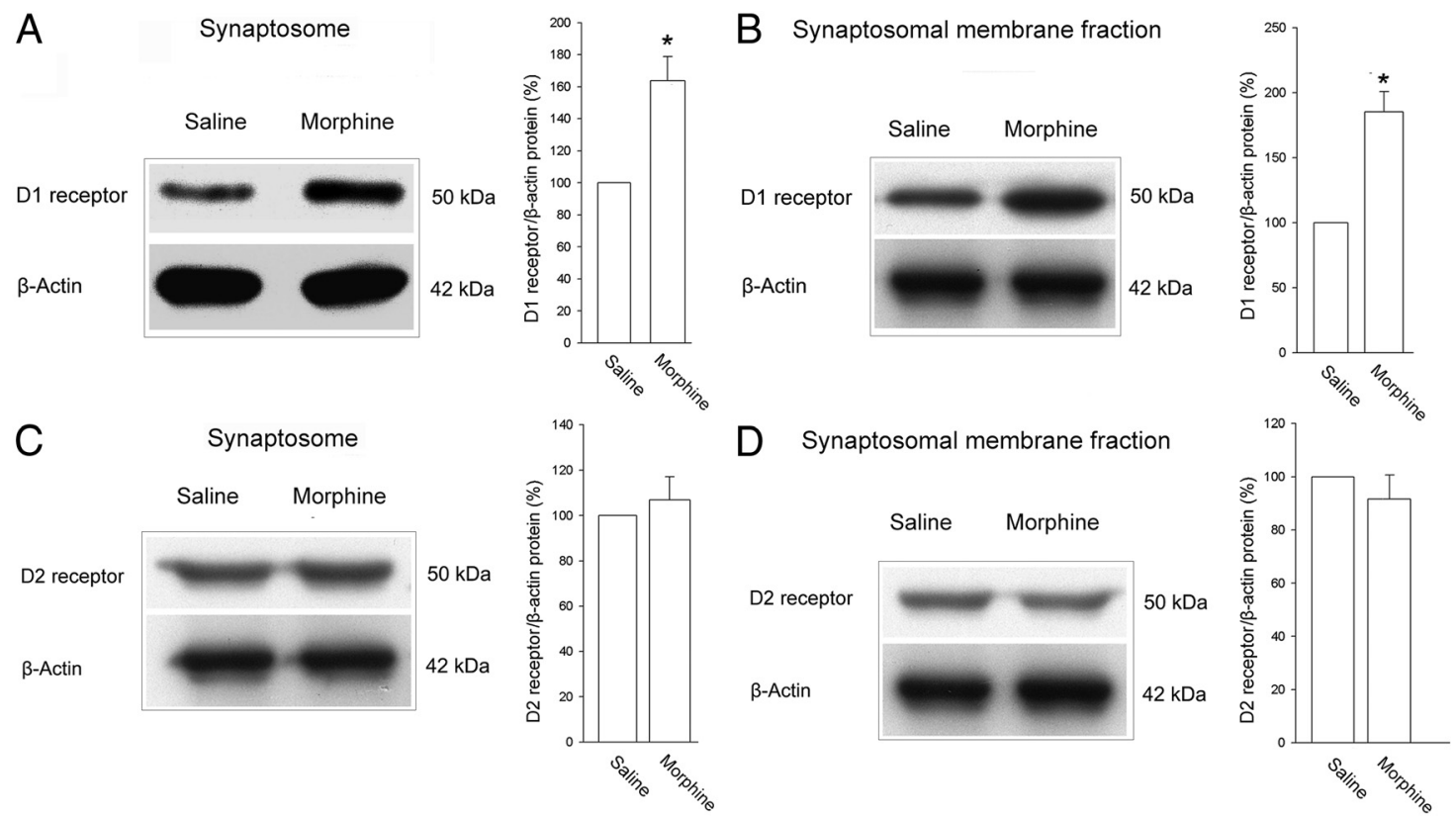

Figure 6. Expression of D1 and D2 receptors in synaptosomes and synaptosomal membrane fraction from the amygdala in the saline-treated and chronic-morphine-treated rats using Western blotting. $\boldsymbol{A}-\boldsymbol{D}$, Left, Immunoblots of the $\mathrm{D} 1$ receptor protein levels in the amygdala after labeling with the antibody in the saline-treated and chronic-morphine-treated rat. Right, Averaged density of the corresponding protein bands after normalization by $\beta$-actin protein in the saline-treated and chronic-morphine-treated rats. $A$, Expression of D1 receptors in synaptosomes $(n=5)$ from the amygdala in the saline-treated and chronic-morphine-treated rats using Western blotting $\left({ }^{*} p<0.05\right.$, compared with the saline-treated group). $\boldsymbol{B}$, Expression of $\mathrm{D} 1$ receptors in synaptosomal membrane fraction $(n=6)$ from the amygdala in the saline-treated and chronic-morphine-treated rats using Western blotting $\left({ }^{*} p<0.05\right.$, compared with the saline-treated group). $C$, Expression of $\mathrm{D} 2$ receptors in synaptosomes $(n=6)$ from the amygdala in the saline-treated and chronic-morphine-treated rats using Western blotting. $\boldsymbol{D}$, Expression of D2 receptors in synaptosomal membrane fraction $(n=6)$ from the amygdala in the saline-treated and chronic-morphine-treated rats using Western blotting.

SCH23390 (10 $\mu \mathrm{M})$ alone had no significant effect on EPSC in the chronic-morphine-treated rats $(n=7$; Fig. 2). Furthermore, we observed the effect of the D1 receptor agonist SKF38393 on EPSC. The result showed that in saline-treated rats, SKF38393 $(10 \mu \mathrm{M})$ had no effect on the amplitude of EPSC ( $n=$ 6), but in chronic-morphine-treated rats, SKF38393 could significantly increase the amplitude of EPSC $(n=6$; Fig. 3$)$.

\section{Site of the effect of chronic morphine treatment on D1 receptors is at presynaptic locus}

To study the site of the effect of chronic morphine treatment on D1 receptors, we observed the effect of the D1 receptor agonist SKF38393 (Cantrell et al., 1997) on the frequency and amplitude of mEPSCs in the saline-treated and chronic-morphine-treated rats. The results showed that in saline-treated rats, SKF38393 (10 $\mu \mathrm{M}$ ) had no significant effect on either frequency or amplitude of $\operatorname{mEPSCs}(n=6$; Fig. $4 A)$, but in chronic-morphine-treated rats, although SKF38393 (10 $\mu \mathrm{M})$ still had no effect on the amplitude of mEPSCs, it could significantly increase the frequency of mEPSCs $(n=6$; Fig. $4 B$ ). We also used PPF of EPSC as another indicator of presynaptic glutamate release. The results showed that in saline-treated rats, SKF38393 $(10 \mu \mathrm{M})$ had no effect on the PPF ( $n=6$; Fig. $5 A)$, but in chronic-morphinetreated rats, after the addition of SKF38393 $(10 \mu \mathrm{M})$, the first EPSC was increased by $51.2 \pm 16.0 \%(n=6)$, but the second synaptic response only by $27.9 \pm 14.3 \%(n=6)$. Therefore, the superimposition of the two traces normalized to the first EPSC under control and SKF38393 showed that PPF was decreased after SKF38393 in chronic-morphine-treated rats (Fig. 5B, left). The averaged PPF in chronic-morphine-treated rats was decreased from $79.8 \pm 16.7 \%$ before to $45.4 \pm 8.1 \%$ at $15-20$ min after SKF38393 $(n=6, p<0.05$; Fig. 5B, right).
This result suggests that in chronic-morphine-treated rats, SKF38393 can increase presynaptic glutamate release. We also examined the expression of D1 receptors in synaptosomes from the amygdala in saline- and chronic-morphine-treated rats using Western blotting. The result showed that chronic morphine treatment could induce a significant increase in the amount of D1 receptor expression in synaptosomes. The percentage of the D1 receptor $/ \beta$-actin was $22.8 \pm 2.0 \%$ in saline-treated rats, but it was $37.4 \pm 3.4 \%$ in chronic-morphine-treated rats, showing a significant increase $(n=5, p<0.05$, compared with saline-treated rats; Fig. $6 A$ ). In addition, using synaptosomal membrane fraction, we obtained a similar result to that of synaptosomes $(n=6, p<0.05$, compared with the salinetreated rats; Fig. $6 \mathrm{~B}$ ). In contrast, chronic morphine treatment had no significant effect on the levels of D2 receptors in either synaptosomes orsynaptosomal membrane fraction $(n=$ $6, p>0.05$; Fig. $6 C, D)$. These results suggest that chronic morphine treatment selectively upregulates the expression of D1 receptors.

\section{Enhancement of glutamate release by D1 receptor agonist upon chronic morphine treatment is dependent on PKA activation}

To determine the involvement of the PKA pathway in the D1 receptor agonist-induced increase of glutamate release upon chronic morphine treatment, we observed the influence of the PKA inhibitor H89 (Chijiwa et al., 1990) on the effect of the D1 receptor agonist SKF38393 on the frequency of mEPSCs. The result showed that in chronic-morphine-treated rats, the preincubation of slices with $\mathrm{H} 89(10 \mu \mathrm{M})$ alone had no effect on the frequency of mEPSCs (the averaged frequency of mEPSCs was $5.51 \pm 0.96 \mathrm{~Hz}$ before and $5.47 \pm 1.04 \mathrm{~Hz}$ after H89; $n=$ 


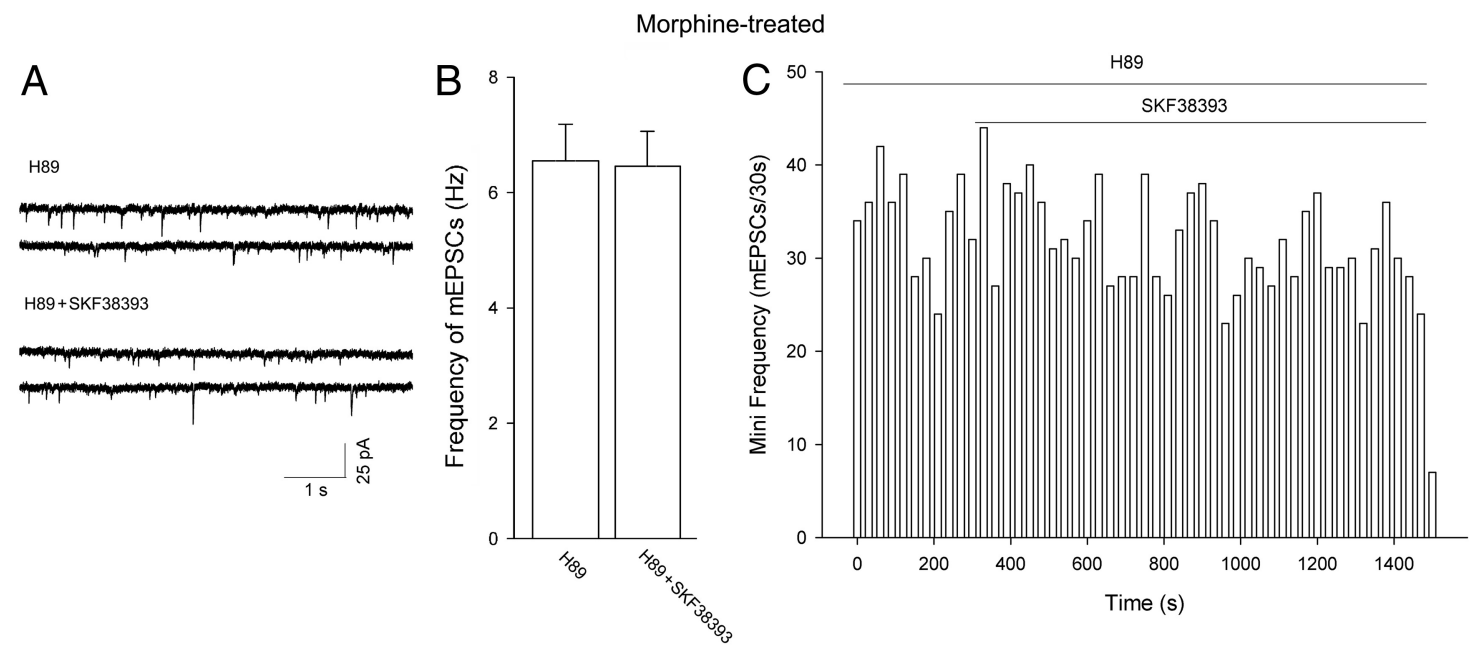

Figure 7. Influence of PKA inhibitor on D1 receptor agonist-induced increase in the frequency of mEPSCs in chronic-morphine-treated rats in the pyramidal cells of BLA. $A$, Typical recordings of mEPSCs before and after SKF38393 (10 $\mu \mathrm{m})$ in the presence of the PKA inhibitor H89 $(10 \mu \mathrm{m})$ in the slice from the chronic-morphine-treated rat. Holding potential, $-70 \mathrm{mV} . \boldsymbol{B}$, Averaged frequency of mEPSCs before and after SKF38393 $(10 \mu \mathrm{M})$ in the presence of H89 $(10 \mu \mathrm{M})$ in the slices from the chronic-morphine-treated rats $(n=6)$. $C$, Time course of the frequency of mEPSCs in a typical cell before and after SKF38393 $(10 \mu \mathrm{M})$ in the presence of $\mathrm{H} 89(10 \mu \mathrm{m})$ in the slice from the chronic-morphine-treated rat.

A
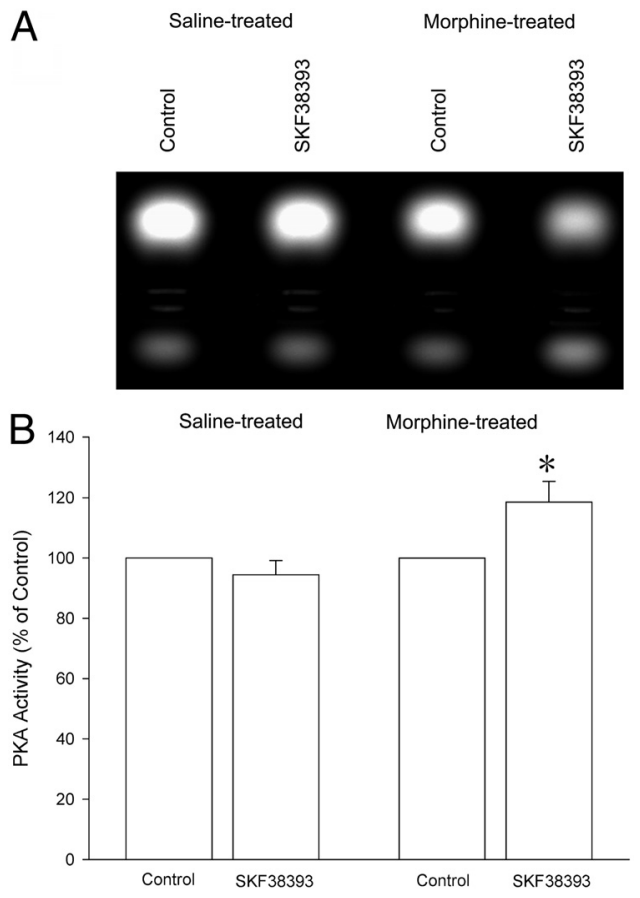

Figure 8. Effect of D1 receptor agonist on the PKA activity in synaptosomes from the amygdala in the saline-treated and chronic-morphine-treated rats. $A$, Representative gel electrophoresis from PKA activity assay before and after the D1 receptor agonist SKF38393 $(10 \mu \mathrm{M})$ in the saline-treated and chronic-morphine-treated rat. $\boldsymbol{B}$, Averaged change percentage of the PKA activity before and after SKF38393 $(10 \mu \mathrm{M})$ in the saline-treated and chronic-morphinetreated rats $\left(n=9,{ }^{*} p<0.05\right.$, compared with control).

$4, p>0.05)$, but H89 completely inhibited the SKF38393induced increase of the frequency of mEPSCs ( $n=6$; Fig. 7 ). We also observed the effect of SKF38393 on the PKA activity in synaptosomes from the amygdala. As shown in Figure 8, in saline-treated rats, SKF38393 $(10 \mu \mathrm{M})$ had no effects on the PKA activity $(n=9, p>0.05)$, but in chronic-morphinetreated rats, SKF38393 significantly increased the PKA activity $(n=9, p<0.05)$.
Intra-BLA injection of D1 receptor antagonist cancels the naloxone-induced conditioned place aversion in morphine-dependent rats

We explored the functional significance of the chronic-morphineinduced change in D1 receptors in BLA. Since previous study showed that selective excitotoxic lesions of BLA could prevent the development of conditioned withdrawal in morphine-dependent rats (Schulteis et al., 2000), we hypothesized that this change in D1 receptors in BLA might be responsible for the withdrawal-induced conditioned place aversion. To test this hypothesis, we examined the influence of the intra-BLA injection of D1 receptor antagonist on the conditioned place aversion in morphine-dependent rats. As shown in Figure 9A, before the naloxone conditioning, there was no difference in baseline pretest CPA scores between the saline and naloxone groups. The averaged pretest CPA score of the naloxone group was $34.6 \pm 16.7 \mathrm{~s}$, which was not statistically significantly different from that of the saline group (33.2 $\pm 32.4 \mathrm{~s})$. But after the naloxone conditioning, the morphine-dependent rats exhibited a strong aversion to the withdrawal-associated compartment. The averaged test CPA score in the naloxone group was $-137.4 \pm 61.0 \mathrm{~s}$, which was statistically significantly reduced compared with the pretest CPA in the naloxone group ( $34.6 \pm 16.7 \mathrm{~s})$. However, after the intra-BLA injection of the D1 receptor antagonist SCH23390 $(0.5 \mu \mathrm{g} /$ side $)$ before naloxone, the place aversion induced by naloxone disappeared in the SCH23390 group (Fig. 9B). The averaged CPA before and after naloxone in the naloxone group without $\mathrm{SCH} 23390$ were $27.8 \pm 60.5 \mathrm{~s}$ and $-123.3 \pm 59.0 \mathrm{~s}(n=8, p<0.05)$, respectively, but they were $12.8 \pm 40.8 \mathrm{~s}$ and $-12.1 \pm 42.0 \mathrm{~s}(n=9, p>0.05)$ in the naloxone group with $\mathrm{SCH} 23390$, respectively.

\section{Discussion}

Dopaminergic inputs from the ventral tegmental area are well positioned to modulate glutamatergic synaptic transmission in the pyramidal cells of BLA (Sesack et al., 2003; Pinto and Sesack, 2008). Previous studies have examined the effect of dopamine on the excitability (Kröner et al., 2005) and the stimulation-evoked NMDA receptor-mediated currents (Pickel et al., 2006) in the pyramidal cells of BLA. However, few studies observed the effect of dopamine on the glutamatergic synaptic transmission mediated by AMPA receptors. One finding of the present study is that 

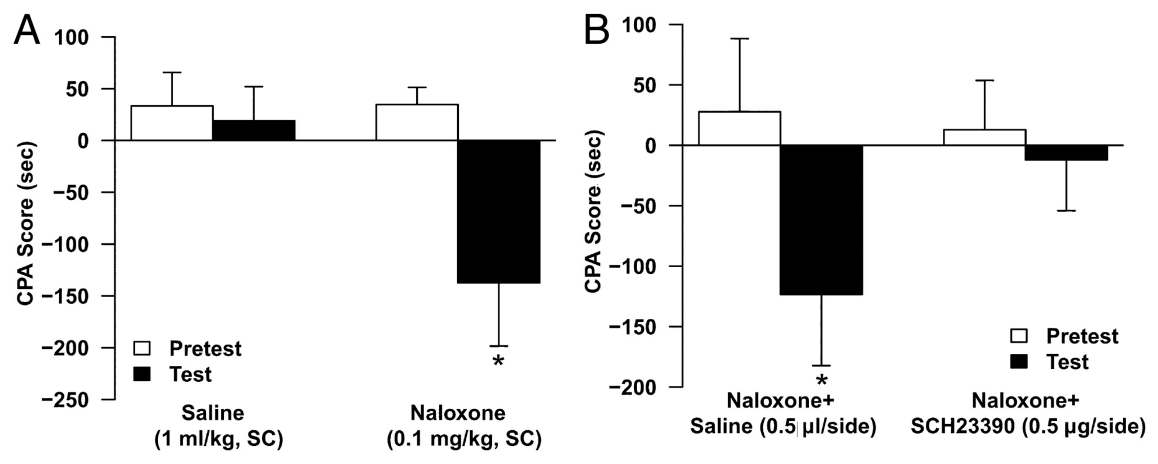

Figure 9. Influence of the intra-BLA injection of D1 receptor antagonist on the naloxone-induced conditioned place aversion in morphine-dependent rats. $A$, Averaged CPA score of the saline and naloxone $(0.1 \mathrm{mg} / \mathrm{kg})$ group in morphine-dependent rats $(n=$ $6,{ }^{*} p<0.05$, compared with the pretest (PA in naloxone group). $\boldsymbol{B}$, Averaged (PA score before and after naloxone in the naloxone group without and with the D1 receptor antagonist $\mathrm{SCH} 23390(0.5 \mu \mathrm{g} / \mathrm{side})(n=8$ in the naloxone group without $\mathrm{SCH} 23390, n=$ 9 in the naloxone group with $\mathrm{SCH} 23390 ;{ }^{*} p<0.05$, compared with the pretest (PA in naloxone group without $\left.\mathrm{SCH} 23390\right)$.

dopamine inhibits the AMPA receptors-mediated synaptic transmission in the pyramidal cells of BLA and, interestingly, after chronic morphine treatment, the effect of dopamine on this excitatory synaptic transmission is switched from inhibition to excitation. To the best of our knowledge, this is the first report involving the switching action of chronic morphine treatment on the effect of dopamine on the AMPA receptors-mediated synaptic transmission in the pyramidal cells of BLA.

The mechanism of the excitatory effect of dopamine on the AMPA receptors-mediated synaptic transmission upon chronic morphine treatment in the pyramidal cells of BLA was the next question we addressed. First, we studied its receptor mechanism. Our results suggested that this excitatory effect of dopamine might be mediated by D1 receptors because if blocking D1 receptors, this excitatory effect disappeared and the D1 receptor agonist could mimic this excitatory effect of dopamine in the chronic-morphine-treated rats. Second, we explored the synaptic site of this D1 receptor-mediated excitatory effect. Our results suggested that this effect might occur at presynaptic site because (1) in the chronic-morphine-treated rats, the D1 receptor agonist had no effect on the mEPSCs amplitude, which was an index of postsynaptic actions (Redman, 1990), but it could significantly increase the mEPSCs frequency, which was a measure of presynaptic actions (Redman, 1990); and (2) in the experiment using PPF of EPSC as another indicator of presynaptic glutamate release (Zucker and Regehr, 2002), the result also showed that the D1 receptor agonist could increase presynaptic glutamate release in the chronic-morphine-treated rats.

Interestingly, under normal conditions, the D1 receptor agonist had no significant effects on the AMPA receptor-mediated synaptic transmission in the pyramidal cells of BLA. The reasons for this absence of effect may be related to the expression and targets of D1 receptors in the pyramidal cells of BLA. Previous electron microscopic studies showed that both D1 and D2 receptors were mainly associated with the plasma membrane of the pyramidal cells of BLA at postsynaptic sites (Pickel et al., 2006; Pinto and Sesack, 2008), but at presynaptic sites, they were found together in only 3.5\% of axon terminals (Muly et al., 2009). Moreover, even at postsynaptic sites, the main target of D1 receptors is NMDA receptors. D1 receptors and NMDA receptors are codistributed due to protein-protein interactions and dopamine can modulate NMDA currents by the D1 receptor-mediated mechanism (Pickel et al., 2006; Martina and Bergeron, 2008). Thus, it is possible that the D1 receptor agonist had no or a weak effect on presynaptic glutamate release in the pyramidal cells of BLA. This hypothesis was confirmed by our result that in normal rats, the $\mathrm{D} 1$ receptor agonist had no effect on presynaptic glutamate release. However, upon chronic morphine treatment, since morphine induced a significant increase in the amount of D1 receptors and in the activity of its downstream molecule PKA in the presynaptic terminals of the pyramidal cells of BLA, the D1 receptor agonist could induce a significant increase in the presynaptic glutamate release.

A potential alternative mechanism for the chronic-morphine-induced enhancement of excitatory synaptic transmission as shown in this study is that there is a reciprocal interaction between D1 and D2 receptors under normal conditions, and upon chronic morphine treatment, the inhibitory reciprocal action from D2 receptors to D1 receptors declines, resulting in D1 receptor-mediated enhancement of excitatory synaptic transmission. However, our results do not appear to support this hypothesis. First, under normal conditions, the D2 receptor antagonist sulpiride $(20 \mu \mathrm{M})$ had no significant effect on dopamine-induced inhibition of EPSC ( $20.0 \pm 4.3 \%$ vs $26.7 \pm 12.5 \%$ without and with sulpiride, respectively; $n=6$ per condition, $p>0.05)$. Sulpiride treatment $(20 \mu \mathrm{M})$ alone had no effect on the amplitude of EPSC (249.0 \pm $22.1 \mathrm{pA}$ vs $236.3 \pm 23.7 \mathrm{pA}$ before and after sulpiride treatment, respectively; $n=6$ per condition, $p>0.05)$. These results are consistent with the notion that D2 receptors are localized mainly in the postsynaptic sites of the pyramidal cells of BLA (Pickel et al., 2006; Pinto and Sesack, 2008). In contrast, at the presynaptic sites, D2 receptors are found only in $3.5 \%$ of axon terminals (Muly et al., 2009). Second, our Western blotting results showed that chronic morphine treatment did not significantly alter the expression levels of D2 receptors in synaptosomes and synaptosomal membrane fraction from the amygdala.

The functional significance of the chronic morphine-induced presynaptic D1 receptor signaling glutamate release enhancement in the pyramidal cells of BLA is interesting to explore. The pyramidal cells of BLA are believed to be critical for the formation of emotion. They receive excitatory glutamatergic inputs and send output signals to mediate emotional behaviors. Thus, it is possible that the enhancement of glutamatergic inputs via increasing presynaptic D1 receptor signaling to the pyramidal cells of BLA upon chronic morphine increases the neuronal activity of the pyramidal cells of BLA and thus shifts the emotional state to an addicted state, which may be one reason for the morphine dependence, as withdrawal of morphine may induce an aversive emotional response. To test this hypothesis, we observed the influence of the intra-BLA local application of the D1 receptor antagonist on the conditioned place aversion induced by naloxone in morphine-dependent rats. The result showed that after the intra-BLA injection of the D1 receptor antagonist before naloxone, CPA induced by naloxone disappeared in the morphinedependent rats, confirming that the chronic morphine-induced D1 receptor signaling enhancement in BLA played an important role in the conditioned withdrawal in morphine-dependent rats. This statement was consistent with the result that selective excitotoxic lesions of BLA could prevent the development of condi- 
tioned withdrawal in morphine-dependent rats (Schulteis et al., 2000).

In conclusion, chronic morphine treatment switches the effect of dopamine on excitatory synaptic transmission from inhibition to excitation by presynaptic D1 receptor amount increase-mediated glutamate release in the pyramidal cells of BLA and the blockade of D1 receptors in BLA cancels CPA in morphine-dependent rats.

\section{References}

Andrzejewski ME, Spencer RC, Kelley AE (2005) Instrumental learning, but not performance, requires dopamine D1-receptor activation in the amygdala. Neuroscience 135:335-345.

Berridge KC, Robinson TE (1998) What is the role of dopamine in reward: hedonic impact, reward learning, or incentive salience? Brain Res Brain Res Rev 28:309-369.

Cantrell AR, Smith RD, Goldin AL, Scheuer T, Catterall WA (1997) Dopaminergic modulation of sodium current in hippocampal neurons via cAMP-dependent phosphorylation of specific sites in the sodium channel alpha subunit. J Neurosci 17:7330-7338.

Chijiwa T, Mishima A, Hagiwara M, Sano M, Hayashi K, Inoue T, Naito K, Toshioka T, Hidaka H (1990) Inhibition of forskolin-induced neurite outgrowth and protein phosphorylation by a newly synthesized selective inhibitor of cyclic AMP-dependent protein kinase, $N$-[2-(p-bromocinnamylamino)ethyl]-5-isoquinolinesulfonamide (H-89), of PC12D pheochromocytoma cells. J Biol Chem 265:5267-5272.

Desjardins S, Belkai E, Crete D, Cordonnier L, Scherrmann JM, Noble F, Marie-Claire C (2008) Effects of chronic morphine and morphine withdrawal on gene expression in rat peripheral blood mononuclear cells. Neuropharmacology 55:1347-1354.

Di Chiara G (1999) Drug addiction as dopamine-dependent associative learning disorder. Eur J Pharmacol 375:13-30.

Di Chiara G, North RA (1992) Neurobiology of opiate abuse. Trends Pharmacol Sci 13:185-193.

Di Ciano P, Everitt BJ (2005) Neuropsychopharmacology of drug seeking: insights from studies with second-order schedules of drug reinforcement. Eur J Pharmacol 526:186-198.

Dong Y, Fu YM, Sun JL, Zhu YH, Sun FY, Zheng P (2005) Neurosteroid enhances glutamate release in rat prelimbic cortex via activation of alpha1-adrenergic and sigmal receptors. Cell Mol Life Sci 62:1003-1014.

Glass MJ, Lane DA, Colago EE, Chan J, Schlussman SD, Zhou Y, Kreek MJ, Pickel VM (2008) Chronic administration of morphine is associated with a decrease in surface AMPA GluR1 receptor subunit in dopamine D1 receptor expressing neurons in the shell and non-D1 receptor expressing neurons in the core of the rat nucleus accumbens. Exp Neurol 210:750-761.

Harmer CJ, Phillips GD (1999) Enhanced dopamine efflux in the amygdala by a predictive, but not a non-predictive, stimulus: facilitation by prior repeated D-amphetamine. Neuroscience 90:119-130.

Hyman SE, Malenka RC, Nestler EJ (2006) Neural mechanisms of addiction: the role of reward-related learning and memory. Annu Rev Neurosci 29:565-598.

Ito M, Nagai T, Mizoguchi H, Sato K, Hayase M, Otsuka N, Fukakusa A, Kumagai N, Kim HC, Nabeshima T, Takuma K, Yamada K (2007) Activation of post-synaptic dopamine $\mathrm{D}(1)$ receptors promotes the release of tissue plasminogen activator in the nucleus accumbens via PKA signaling. J Neurochem 103:2589-2596.

Kreek MJ (2001) Drug addictions: molecular and cellular endpoints. Ann N Y Acad Sci 937:27-49.

Kröner S, Rosenkranz JA, Grace AA, Barrionuevo G (2005) Dopamine modulates excitability of basolateral amygdala neurons in vitro. J Neurophysiol 93:1598-1610.

Lou LG, Pei G (1997) Modulation of protein kinase C and cAMPdependent protein kinase by delta-opioid. Biochem Biophys Res Commun 236:626-629.

Lowry OH, Rosebrough NJ, Farr AL, Randall RJ (1951) Protein measurement with the Folin phenol reagent. J Biol Chem 193:265-275.

Martina M, Bergeron R (2008) D1 and D4 dopaminergic receptor interplay mediates coincident $\mathrm{G}$ protein-independent and dependent regulation of glutamate NMDA receptors in the lateral amygdala. J Neurochem 106:2421-2435.

McClung CA, Nestler EJ, Zachariou V (2005) Regulation of gene expression by chronic morphine and morphine withdrawal in the locus ceruleus and ventral tegmental area. J Neurosci 25:6005-6015.
Michaeli A, Yaka R (2010) Dopamine inhibits GABA(A) currents in ventral tegmental area dopamine neurons via activation of presynaptic G-protein coupled inwardly-rectifying potassium channels. Neuroscience 165:1159-1169.

Momiyama T, Sim J, Brown D (1996) Dopamine D1-like receptormediated presynaptic inhibition of excitatory transmission onto rat magnocellular basal forebrain neurons. J Physiol 495:97-106.

Moore RA, Nguyen H, Galceran J, Pessah IN, Allen PD (1998) A transgenic myogenic cell line lacking ryanodine receptor protein for homologous expression studies: reconstitution of Ry1R protein and function. J Cell Biol 140:843-851.

Muller JF, Mascagni F, McDonald AJ (2009) Dopaminergic innervation of pyramidal cells in the rat basolateral amygdala. Brain Struct Funct 213:275-288.

Muly EC, Senyuz M, Khan ZU, Guo JD, Hazra R, Rainnie DG (2009) Distribution of D1 and D5 dopamine receptors in the primate and rat basolateral amygdala. Brain Struct Funct 213:375-393.

Nakano Y, Lénárd L, Oomura Y, Nishino H, Aou S, Yamamoto T (1987) Functional involvement of catecholamines in reward-related neuronal activity of the monkey amygdala. J Neurophysiol 57:72-91.

Narita M, Matsushima Y, Niikura K, Narita M, Takagi S, Nakahara K, Kurahashi K, Abe M, Saeki M, Asato M, Imai S, Ikeda K, Kuzumaki N, Suzuki $\mathrm{T}$ (2010) Implication of dopaminergic projection from the ventral tegmental area to the anterior cingulate cortex in mu-opioid-induced place preference. Addict Biol 15:434-447.

Nicola SM, Kombian SB, Malenka RC (1996) Psychostimulants depress excitatory synaptic transmission in the nucleus accumbens via presynaptic D1-like dopamine receptors. J Neurosci 16:1591-1604.

Paxinos G, Watson C (2005) The rat brain in stereotaxic coordinates, Ed 5. San Diego: Elsevier Academic.

Pickel VM, Colago EE, Mania I, Molosh AI, Rainnie DG (2006) Dopamine D1 receptors co-distribute with $N$-methyl-D-aspartic acid type-1 subunits and modulate synaptically-evoked $N$-methyl-D-aspartic acid currents in rat basolateral amygdala. Neuroscience 142:671-690.

Pinto A, Sesack SR (2008) Ultrastructural analysis of prefrontal cortical inputs to the rat amygdala: spatial relationships to presumed dopamine axons and D1 and D2 receptors. Brain Struct Funct 213:159-175.

Redman S (1990) Quantal analysis of synaptic potentials in neurons of the central nervous system. Physiol Rev 70:165-198.

Schulteis G, Ahmed SH, Morse AC, Koob GF, Everitt BJ (2000) Conditioning and opiate withdrawal. Nature 405:1013-1014.

Schultz W (2000) Multiple reward signals in the brain. Nat Rev Neurosci 1:199-207.

Seamans JK, Durstewitz D, Christie BR, Stevens CF, Sejnowski TJ (2001) Dopamine D1/D5 receptor modulation of excitatory synaptic inputs to layer V prefrontal cortex neurons. Proc Natl Acad Sci U S A 98:301-306.

See RE (2005) Neural substrates of cocaine-cue associations that trigger relapse. Eur J Pharmacol 526:140-146.

Sesack SR, Carr DB, Omelchenko N, Pinto A (2003) Anatomical substrates for glutamate-dopamine interactions: evidence for specificity of connections and extrasynaptic actions. Ann N Y Acad Sci 1003:36-52.

Spanagel R, Weiss F (1999) The dopamine hypothesis of reward: past and current status. Trends Neurosci 22:521-527.

Valverde O, Tzavara E, Hanoune J, Roques BP, Maldonado R (1996) Protein kinases in the rat nucleus accumbens are involved in the aversive component of opiate withdrawal. Eur J Neurosci 8:2671-2678.

Visanji NP, Wislet-Gendebien S, Oschipok LW, Zhang G, Aubert I, Fraser PE, Tandon A (2011) The effect of S129 phosphorylation on the interaction of alpha-synuclein with synaptic and cellular membranes. J Biol Chem 286:35863-35873.

Wang Z, Zheng P (2001) Characterization of spontaneous excitatory synaptic currents in pryamidal cells of rat prelimbic cortex. Brain Res 901:303313.

Zhou FM, Hablitz JJ (1999) Dopamine modulation of membrane and synaptic properties of interneurons in rat cerebral cortex. J Neurophysiol 81:967-976.

Ziolkowska B, Gieryk A, Bilecki W, Wawrzczak-Bargiela A, Wedzony K, Chocyk A, Danielson PE, Thomas EA, Hilbush BS, Sutcliffe JG, Przewlocki R (2005) Regulation of alpha-synuclein expression in limbic and motor brain regions of morphine-treated mice. J Neurosci 25:4996-5003.

Zucker RS, Regehr WG (2002) Short-term synaptic plasticity. Annu Rev Physiol 64:355-405. 